\title{
CONCEPT FORMATION: PHYSICS TEACHER AND HIS KNOW-HOW AND KNOW-WHY
}

\author{
Peter Demkanin \\ Comenius University in Bratislava, Slovakia
}

Physics education is an easy job, making people happy. It is an easy job for all, including teachers and learners. Do you agree? I do, but probably it is good to try to discuss these words somehow in details.

Quite often we see, even in our Journal, research results proving that Physics is not so popular. Physics courses require thinking, using correct words, not making too much algebra and calculation mistakes, using arguments. Really, a reasonable portion of pupils does not find Physics lessons as a source of happiness. What to do with these pupils, their teachers and the content they are taught? Neuroscientists, like M. Lieberman, are converging to interesting ideas: "Teachers are losing the education war because our adolescents are distracted by the social world. Naturally, the students don't see it that way. It wasn't their choice to get endless instruction on topics that don't seem relevant to them. They desperately want to learn, but what they want to learn about is their social world - how it works and how they can secure a place in it that will maximize their social rewards and minimize the social pain they feel. Their brains are built to feel these strong social motivations and to use the mentalizing system to help them along. Evolutionarily, the social interest of adolescents is no distraction. Rather, it is the most important thing they can learn well." (Lieberman 2013, p.282)

The idea, that a teacher-beginner is teaching his students as he has been taught is generally well accepted. It is not easy to rebuild the knowledge system of a teacher, to engraft evidence-based perspective on the Physics education, to train him for conscious using of up-to-date best practices. A teacher, to be successful, must be trained in each of the basic dimensions -knowledge, abilities, and relationships. These dimensions are mutually interwoven in the process of teaching. Every day, at every lesson, they are applied jointly. Let us take, as an example, the Archimedes principle and a teacher facilitating the learning of the Archimedes principle at a lower secondary school. The teacher is, at the same time, using, e.g. his knowledge of the forces, pressure, relevant pupil's representations; his abilities to aim the attention of the group of pupils, to manipulate equipment and focus pupil's attention to important issues of the experiment used. Also, he enters into interrelationships with pupils and this should not be regarded as something odd. Each Physics teacher is a teacher of learners and a teacher of content. A teacher is fulfilled, happy, if he is well educated and trained, if he has well developed all three dimensions - knowledge, abilities, and relationships, if there is an order in his ideas and attitudes. Research results can help in making such order.

During the previous months, I was finishing a university textbook for Physics teachers, a sort of textbook trying to scaffold users, especially future Physics teachers, to see their future pupils as living people, as children and teenagers living in a society, living on Earth. It was quite a long-term endeavour to find a system to help physics teachers to arrange the physics content to be taught. The result is presented on the next lines and schemes. Later in this article, I will mention also a well usable personality model, to balance the idea that a teacher is a teacher of content as well as a teacher of learners. 
ISSN 1648-3898/Print/

ISSN 2538-7138/Online/

Let us look back at a Physics teacher facilitating the learning of the Archimedes principle. The process of teaching physics content is quite often regarded as a process from a naive representation towards the normative knowledge, via instructions (Figure 1). We prefer not to talk about instructions itself but about pupils' thinking and info processing. The information involved in these thinking processes is often gathered empirically (Figure 2). It seems profitable to study the substructure of an event of learning deeply. Some results of such deep study are presented in Sawyer (2015) and diSessa (2014). In Figure 2 we also highlighted methods of Physics Education - Tutoring, Mentoring, Coaching, and Scaffolding, which well leads to fulfilling the goals of Science education.

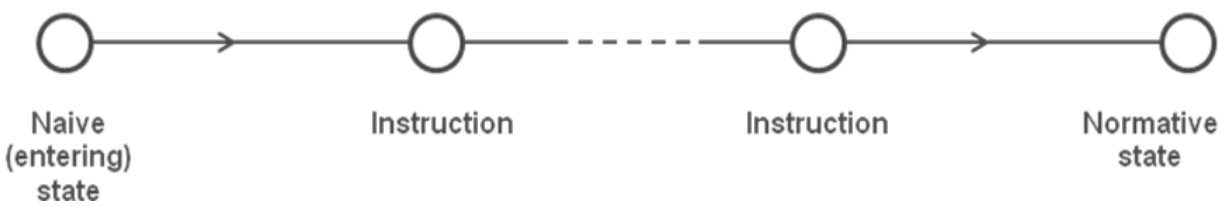

Figure 1: Teacher-centred view of teaching.

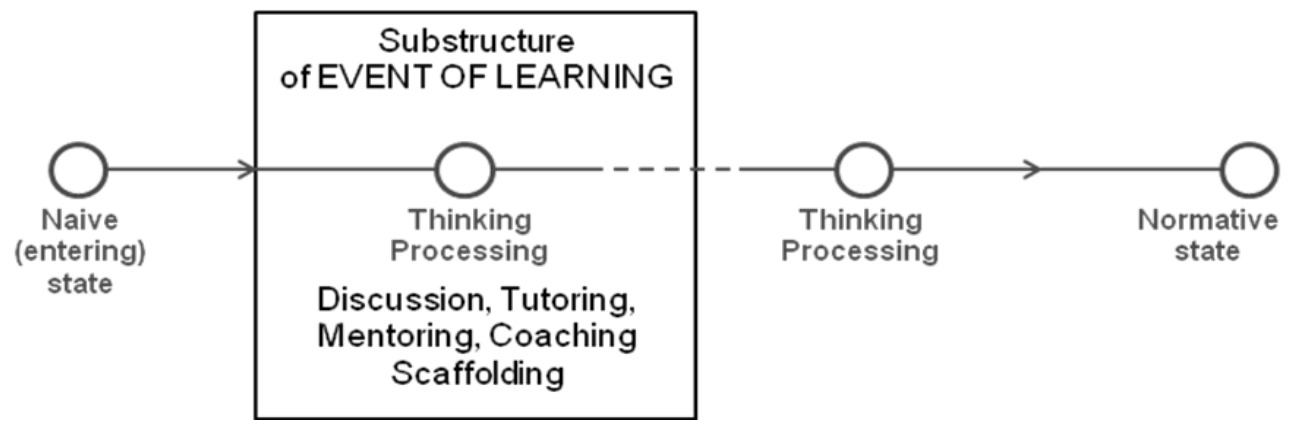

Figure 2: The learner-centred view of teaching with highlighted one event of learning.

To make the Physics education easier, more predictable for pupils as well as for teachers, we have prepared an easy-to-use scheme of the substructure of an event of learning, applicable for concept formation. In Figure 3 (Velanova, 2015), as well as in real Physics lessons, we use mutually linked teaching-learning sequences. Concepts can be regarded as gestalts and within the perception approach the main motto is "meaning first". Concepts are assimilated in the mind as new structural elements and become elements for further perception.

Units of Physics education consist of "activities", Teaching-Learning sequences. Most of the T-L sequences are set to a well-chosen context, the attention of pupils is intentionally aimed to relevant previous knowledge, howbeit naive. The $T-L$ sequence is fertilized by a discussion with peers and adults. The ideas gathered via the $T-L$ sequence are summarised with the help of the teacher managing the teaching-learning processes. Science itself is a never-ending story, so, even if the school education has its time limits, we always, even carefully, doubt, open a dispute or add some complementarities. We go to a next T-L sequence set to a different context, or we go to the final, normative state of a concept, fostering the relevance of the taught curriculum, by application of the new knowledge. Teaching-learning sequences are mutually connected by main, leading idea. In our scheme, we use the term Big Ideas similarly as it is used by W. Harlen (2015). Some of the contexts used should be selected having in mind the idea "pupils must do what they want (at least sometimes)". The context of an inquiry or the context of technology innovation must not be omitted in Physics education. The small section of the scheme, Other goals of Science Education are also important. We fulfil many other goals apart from the content including goals connected to creativity and critical thinking (e.g. Velmovská \& Bartošovič, 2016). Our work with teachers and pupils prove, that this scheme helps in bringing order to the process of teaching-learning, lowering the cognitive demands laid on teachers, making the process of Physics education more predictable for pupils and their parents, so it contributes to psychological safety and happiness of all involved. 


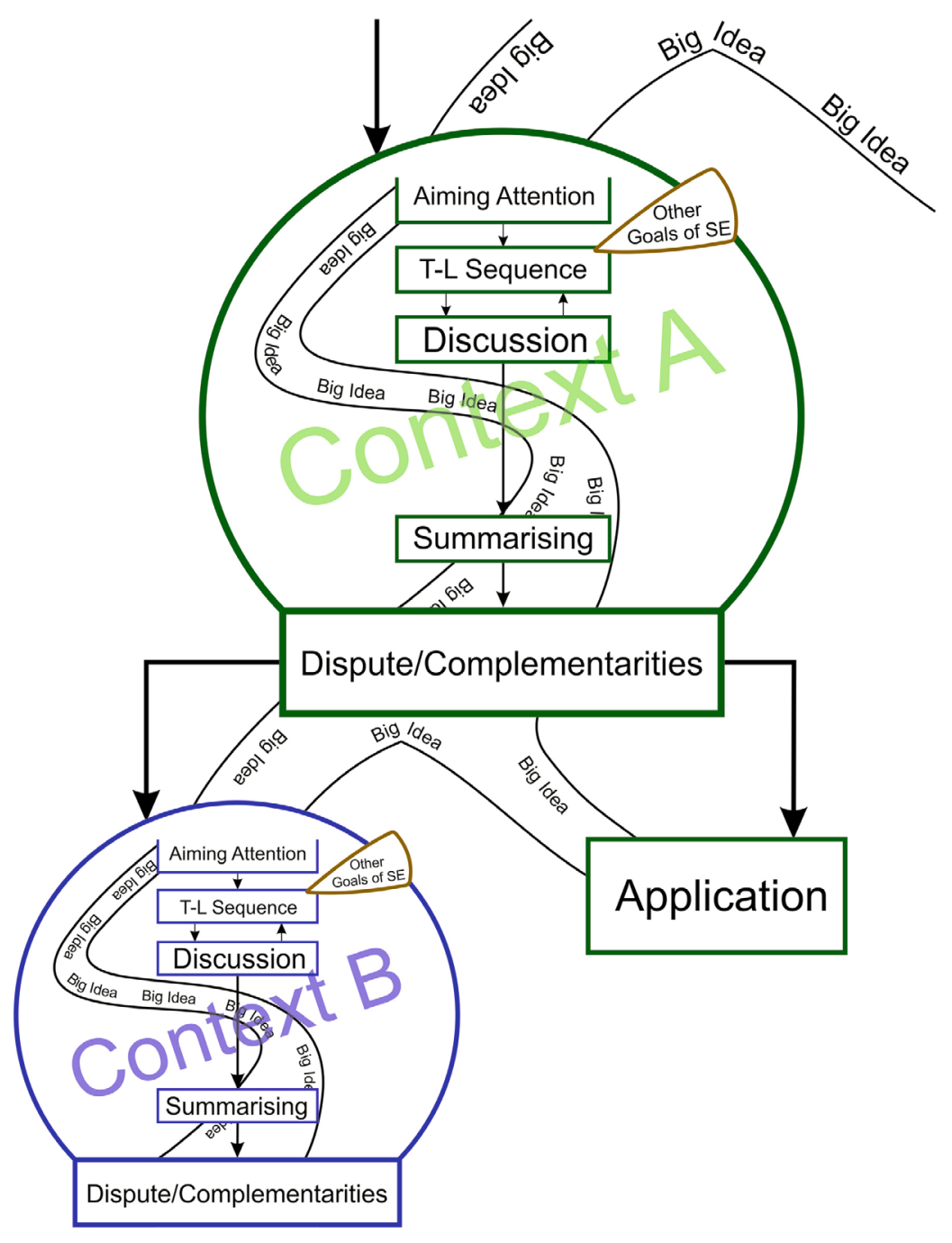

Figure 3: The scheme of concept formation.

To give also another impetus for future research, I would like to mention a great work of R.C.Cloninger, psychologist, who improved the model of personality in a way useful for understanding some of the processes of Science education. Our students are taught, usually by our colleagues, university psychology teachers, many ideas of personality, usually based on the work of S.Freud, A. Freud, K. Joung, H.Suliven, S.Peck or E.Fromm (Demkaninová, 2015). Yes, their work has many reasonable implications for physics teachers today, but psychology itself has made a great step over the last 50 years. R.C.Cloninger, as M. Lieberman who is already mentioned in this article, uses research-based knowledge on neuroscience and, in a not so extensive article, What Makes People Healthy, Happy, and Fulfilled In The Face Of Current World Challenges? (Cloninger, 2013), gives an impetus for the future work on education. The process of facilitating learning of, say, the Archimedes principle, is also about working with student's personality (Demkanin \& Gergel'ová, 2017). Having this idea in mind, together with a well-sequenced content set to well-chosen contexts, a teacher, knowing how and knowing why, can make lessons enjoyable, based on researchbased, evidence-based attitudes to science education, based on the results of research presented also in this Journal. 
ISSN 1648-3898 /Print/

ISSN 2538-7138/Online/

\section{Acknowledgements}

The author is grateful to support from the Slovak Research and Development Agency under the contract APVV-14-0070.

\section{References}

Cloninger, R. C. (2013). What makes people healthy, happy, and fulfilled in the face of current world challenges? Mens Sana Monographs, 11 (1), 16-24. doi: 10.4103/0973-1229.109288.

Demkanin, P. (2013). Preparation of new physics teachers from various perspectives. Journal of Baltic Science Education, 12 (1), 4-5.

Demkanin, P., \& Gergel'ová, B. (2017). Development of aptitude for team work via physics education. In: AIP Conference Proceedings, Volume 1804. American Institute of Physics Inc. doi: 10.1063/1.4974380.

Demkanin, P., \& Velanová, M. (2016). Klúčové tézy obsahu prírodovedného vzdelávania ako kritérium výberu obsahu pre prírodovedné kurikulum [Key theoretical thesis of the content of science education as a criterion for choosing content for the science curriculum]. In Held, L. Východiská prípravy prírodovedného kurikula pre základnú školu 2020 II (pp. 21-44). Trnava: Typi Universitatis Tyrnaviensis.

Demkaninová, D. (2015). Osobnost’ v kontexte ADHD [Personality in the context of ADHD]. In Herényiová, G. ADHD v bio-psychosociálnom kontexte. Bratislava: Psychoprof.

diSessa, A. (2014). The construction of causal schemes: Learning mechanisms at the knowledge level. Cognitive Science, 38 (5), 795-850. doi: 10.1111/cogs.12131.

Harlen, W. (2015). Working with big ideas of science education. Trieste: Science Education Programme of IAP.

Lieberman, M. (2013). Social: Why our brains are wired to connect. Crown.

Sawyer, R. (2015). The Cambridge handbook of the learning sciences. Cambridge University Press.

Velanová, M. (2015). Zavádzanie fyzikálnych pojmov v gymnaziálnom vzdelávaní [Introduction of physical concepts in gymnasium education]. Unpublished doctoral thesis. Comenius University, Bratislava

Velmovská, K., \& Bartošovič, L. (2016). Developing critical thinking skills in physics classes. In Critical thinking: Theories, methods and challenges (pp. 21-43). New York: Nova Science Publishers. 